\title{
Tissue-engineered, hydrogel-based endothelial progenitor cell therapy robustly revascularizes ischemic myocardium and preserves ventricular function
}

\author{
Pavan Atluri, MD, ${ }^{\mathrm{a}}$ Jordan S. Miller, PhD, ${ }^{\mathrm{b}}$ Robert J. Emery, MS, ${ }^{\mathrm{a}}$ George Hung, BA, ${ }^{\mathrm{a}}$ Alen Trubelja, BS, ${ }^{\mathrm{a}}$ \\ Jeffrey E. Cohen, MD, ${ }^{\mathrm{d}}$ Kelsey Lloyd, BS, ${ }^{\mathrm{a}}$ Jason Han, BS, ${ }^{\mathrm{a}}$ Ann C. Gaffey, MD, ${ }^{\mathrm{a}}$ John W. MacArthur, MD, ${ }^{\mathrm{a}}$ \\ Christopher S. Chen, MD, PhD, ${ }^{c}$ and Y. Joseph Woo, MD $^{\mathrm{d}}$
}

\begin{abstract}
Objectives: Cell-based angiogenic therapy for ischemic heart failure has had limited clinical impact, likely related to low cell retention $(<1 \%)$ and dispersion. We developed a novel, tissue-engineered, hydrogel-based cell-delivery strategy to overcome these limitations and provide prolonged regional retention of myocardial endothelial progenitor cells at high cell dosage.
\end{abstract}

\begin{abstract}
Methods: Endothelial progenitor cells were isolated from Wistar rats and encapsulated in fibrin gels. In vitro viability was quantified using a fluorescent live-dead stain of transgenic enhanced green fluorescent protein ${ }^{+}$endothelial progenitor cells. Endothelial progenitor cell-laden constructs were implanted onto ischemic rat myocardium in a model of acute myocardial infarction (left anterior descending ligation) for 4 weeks. Intramyocardial cell injection $\left(2 \times 10^{6}\right.$ endothelial progenitor cells), empty fibrin, and isolated left anterior descending ligation groups served as controls. Hemodynamics were quantified using echocardiography, Doppler flow analysis, and intraventricular pressurevolume analysis. Vasculogenesis and ventricular geometry were quantified. Endothelial progenitor cell migration was analyzed by using endothelial progenitor cells from transgenic enhanced green fluorescent protein ${ }^{+}$rodents.
\end{abstract}

\begin{abstract}
Results: Endothelial progenitor cells demonstrated an overall 88.7\% viability for all matrix and cell conditions investigated after 48 hours. Histologic assessment of 1-week implants demonstrated significant migration of transgenic enhanced green fluorescent protein $^{+}$endothelial progenitor cells from the fibrin matrix to the infarcted myocardium compared with intramyocardial cell injection $(28 \pm 12.3$ cells/high power field vs $2.4 \pm 2.1$ cells/high power field, $P=.0001)$. We also observed a marked increase in vasculogenesis at the implant site. Significant improvements in ventricular hemodynamics and geometry were present after endothelial progenitor cell-hydrogel therapy compared with control.
\end{abstract}

Conclusions: We present a tissue-engineered, hydrogel-based endothelial progenitor cell-mediated therapy to enhance cell delivery, cell retention, vasculogenesis, and preservation of myocardial structure and function. (J Thorac Cardiovasc Surg 2014;148:1090-8)

Ischemic heart failure is a major global health concern. Medical and surgical therapies for heart failure largely have been palliative. Although we have been able to

From the Division of Cardiovascular Surgery, ${ }^{\text {a }}$ Department of Surgery, Perelman School of Medicine, University of Pennsylvania, Philadelphia, Pa; Department of Bioengineering, ${ }^{\mathrm{b}}$ Rice University, Houston, Tex; Department of Biomedical Engineering, ${ }^{\mathrm{c}}$ Boston University, Boston, Mass; and Department of Cardiothoracic Surgery, ${ }^{\mathrm{d}}$ Stanford University, Stanford, Calif.

This project was supported by the National Institutes of Health, National Heart, Lung, Blood Institute Grant 1RO1 HL089315 (to Y.J.W.); the American Association for Thoracic Surgery, David C. Sabiston Research Scholarship (to P.A.); and the American Heart Association, Scientist Development Grant 13SDG17230005 (to P.A.)

Disclosures: Authors have nothing to disclose with regard to commercial support.

Read at the 94th Annual Meeting of The American Association for Thoracic Surgery, Toronto, Ontario, Canada, April 26-30, 2014.

Received for publication April 27, 2014; revisions received June 10, 2014; accepted for publication June 11, 2014

Address for reprints: Y. Joseph Woo, MD, Department of Cardiothoracic Surgery, Stanford University School of Medicine, Falk Bldg CV-235, 300 Pasteur Dr,

Stanford, CA 94305-5407 (E-mail: joswoo@stanford.edu).

$0022-5223 / \$ 36.00$

Copyright (c) 2014 by The American Association for Thoracic Surgery

http://dx.doi.org/10.1016/j.jtcvs.2014.06.038 successfully reduce mortality from acute myocardial infarctions, the progression to ischemic heart failure has not been ameliorated. ${ }^{1-3}$ The concept of postnatal vasculogenesis has been widely investigated for molecular therapy to revascularize ischemic myocardium. Endothelial progenitor cells (EPCs) are pluripotent, bone marrow-derived stem cells with the ability to differentiate into de novo vasculature. Initial enthusiasm was focused on genetic and cytokine therapy to locally recruit EPCs to ischemic myocardium. Subsequent studies have attempted to use cell therapy to directly deliver EPCs locally to the myocardium. Although significant neovasculogenic responses have been seen in small and large animal trials, this benefit has not been translatable to the clinical setting.

Much concern has been raised about cell delivery, dispersal, and engraftment. Cell tracking has demonstrated that less than $1 \%$ of cells remain after direct myocardial injection. ${ }^{4-7}$ We propose a novel therapy, whereby engineered fibrin gel constructs encapsulating EPCs can overcome 

Abbreviations and Acronyms
DAPI $=4^{\prime}, 6$-diamidino-2-phenylindole
$\mathrm{eGFP}=$ enhanced green fluorescent protein
$\mathrm{EPC}=$ endothelial progenitor cell
FITC = fluorescein isothiocyanate
hpf $=$ high power field
LAD $=$ left anterior descending
PBS = phosphate-buffered saline
$\mathrm{SMA}=$ smooth muscle actin

these limitations by providing an environment in which the cells can thrive, enabling an insult-free delivery to ischemic myocardium in high cellular concentration for a prolonged period. In this strategy, EPCs are thought to promote neovasculogenesis by primarily forming de novo vasculature. In addition, EPCs demonstrate paracrine capabilities by eluting proangiogenic cytokines that induce vessel growth by promoting the migration and proliferation of circulating endothelial progenitor/precursor cells. ${ }^{8,9}$ Hydrogels are biocompatible materials capable of providing the microenvironment necessary to allow cell viability and migration to ischemic myocardium after delivery. Fibrin, once polymerized by thrombin, is a particularly attractive biogel that is part of the normal hemostatic pathway and thus is entirely biocompatible. It is already approved for clinical use, thereby facilitating rapid clinical translatability of this therapy. We hypothesize that engineered gels seeded with EPCs at high cellular density will allow high cellular retention rates with direct migration of a large proportion of stem cells to ischemic myocardium.

\section{METHODS}

\section{Animal Care and Biosafety}

Male adult Wistar rats (250-300 g) were obtained from Charles River Laboratories (Boston, Mass). Food and water were provided ad libitum. This investigation adheres to the Guide for the Care and Use of Laboratory Animals published by the US National Institutes of Health (8th ed, revised 2011). This study conforms to institutional ethical review and has been approved by the University of Pennsylvania Institutional Animal Care and Use Committee. All measurements were performed by investigators blinded to animal treatment.

\section{Endothelial Progenitor Cell Isolation}

Bone marrow mononuclear cells were isolated from the long bones of syngeneic adult, male Wistar rats by density-gradient centrifugation (Histopaque 1083; Sigma, St Louis, Mo). After isolation, the cells were seeded on a vitronectin-coated dish. The cells were cultured in endothelial basal medium-2 supplemented with EGM-2 singlequot containing human epidermal growth factor, fetal bovine serum, vascular endothelial growth factor, human fibroblast growth factor-B, R3-insulin-like growth factor I, ascorbic acid, heparin, gentamicin, and amphotericin-B for 6 days (Lonza, Basel, Switzerland). A subset of EPCs were isolated from transgenic rats ubiquitously expressing enhanced green fluorescent protein (eGFP), with a 2-point mutation to enhance spectral characteristics, fluorescence, and stability, which we made use of for cell fate tracking purposes. The eGFP colony was prepared from eGFP transgene (cDNA fragment of eGFP derived from phosphorylated eGFP vector No. 6077-1, Clontech Laboratories [Mountain View, Calif], and pCXN2 expression vector containing cytomegalovirus enhancer, chicken b-actin enhancer-promoter, and rabbit b-globin poly(A) signal), obtained from Dr Kobayashi, Jichi Medical School, Tochigi, Japan. ${ }^{10}$ EPC phenotype (DiLDL ${ }^{+}$VEGFR $2{ }^{+} \mathrm{CD} 34^{+}$) was confirmed as previously published by our group. ${ }^{11,12}$

\section{Endothelial Progenitor Cell Fibrin Hydrogel Construct Creation}

To form the $20 \mathrm{mg} / \mathrm{mL}$ fibrin gels, $5.32 \mathrm{mg}$ of fibrinogen (Sigma, St Louis, $\mathrm{Mo}$ ) was added to phosphate-buffered saline (PBS) and added to the appropriate quantity of EPCs for a final volume of $266 \mu \mathrm{L}$. To manufacture the $10 \mathrm{mg} / \mathrm{mL}$ fibrin gels, $2.66 \mathrm{mg}$ of Fibrinogen (Sigma) was added to PBS and added to the appropriate quantity of EPCs for a final volume of $266 \mu \mathrm{L}$. After preparation of the fibrinogen and EPC mixture in PBS, this $266 \mu \mathrm{L}$ of mixture was mixed into 0.333 Units of thrombin (Sigma); $100 \mu \mathrm{L}$ of this liquid mixture was pipetted directly onto the center of a rectangular piece of Vicryl mesh $(\sim 15 \times 12 \mathrm{~mm})$ to provide integrity for implant.

\section{In Vitro Analysis of Endothelial Progenitor Cell Migration and Viability Within the Construct}

To assess the viability of EPCs embedded into fibrin-derived gels, EPCs were embedded into fibrin-derived gels as described earlier. After gel preparation, the LIVE/DEAD Viability/Cytotoxicity Kit (Invitrogen, Carlsbad, Calif) was used to determine the percentage of viable EPCs, according to manufacturer instructions. Samples were visualized on a DF5000B Leica fluorescent microscope and analyzed using LASAF version 2.0.2 software (Leica, Wetzlar, Germany).

\section{Induction of Heart Failure}

Male Wistar rats were anesthetized in an induction chamber (VetEquip; Ethicon, Blue Ash, Ohio) with 3\% isofluorane, endotracheally intubated, and mechanically ventilated (Hallowell EMC; Ethicon) with $1.0 \%$ isoflurane. A left fourth interspace thoracotomy was performed, and the left anterior descending (LAD) coronary artery was ligated with a 7-0 Prolene suture at the level of the left atrial appendage. This induced a consistent and reproducible anterolateral infarction of $35 \%$ to $40 \%$ of the left

TABLE 1. In vitro endothelial progenitor cell viability within endothelial progenitor cell-fibrin hydrogel constructs

\begin{tabular}{lccc}
\hline \multicolumn{1}{c}{ Construct composition } & Day 2 & Day 6 & Day 10 \\
\hline $5 \mathrm{mg} / \mathrm{mL}$ fibrin $7 \times 10^{6}$ cells $/ \mathrm{mL}$ & $85.9 \% \pm 3.2 \%$ & $65.2 \% \pm 8.5 \%$ & $48.7 \% \pm 1.8 \%$ \\
$5 \mathrm{mg} / \mathrm{mL}$ fibrin $17 \times 10^{6}$ cells $/ \mathrm{mL}$ & $80.8 \% \pm 4.7 \%$ & $71.9 \% \pm 6.1 \%$ & $56.9 \% \pm 3.5 \%$ \\
$10 \mathrm{mg} / \mathrm{mL}$ fibrin $7 \times 10^{6}$ cells $/ \mathrm{mL}$ & $89.1 \% \pm 2.3 \%$ & $61.3 \% \pm 5.6 \%$ & $44.8 \% \pm 5.3 \%$ \\
$10 \mathrm{mg} / \mathrm{mL}$ fibrin $17 \times 10^{6} \mathrm{cells} / \mathrm{mL}$ & $85.2 \% \pm 3.6 \%$ & $59.5 \% \pm 3.7 \%$ & $66.0 \% \pm 5.8 \%$ \\
$20 \mathrm{mg} / \mathrm{mL}$ fibrin $7 \times 10^{6}$ cells $/ \mathrm{mL}$ & $90.3 \% \pm 2.9 \%$ & $63.7 \% \pm 5.4 \%$ & $45.4 \% \pm 4.8 \%$ \\
$20 \mathrm{mg} / \mathrm{mL}$ fibrin $17 \times 10^{6}$ cells $/ \mathrm{mL}$ & $88.3 \% \pm 3.7 \%$ & $73.5 \% \pm 2.8 \%$ & $55.0 \% \pm 4.2 \%$ \\
\hline
\end{tabular}

Viability is demonstrated as percent live cells compared with overall cell density ( $\mathrm{n}=6 /$ group) 


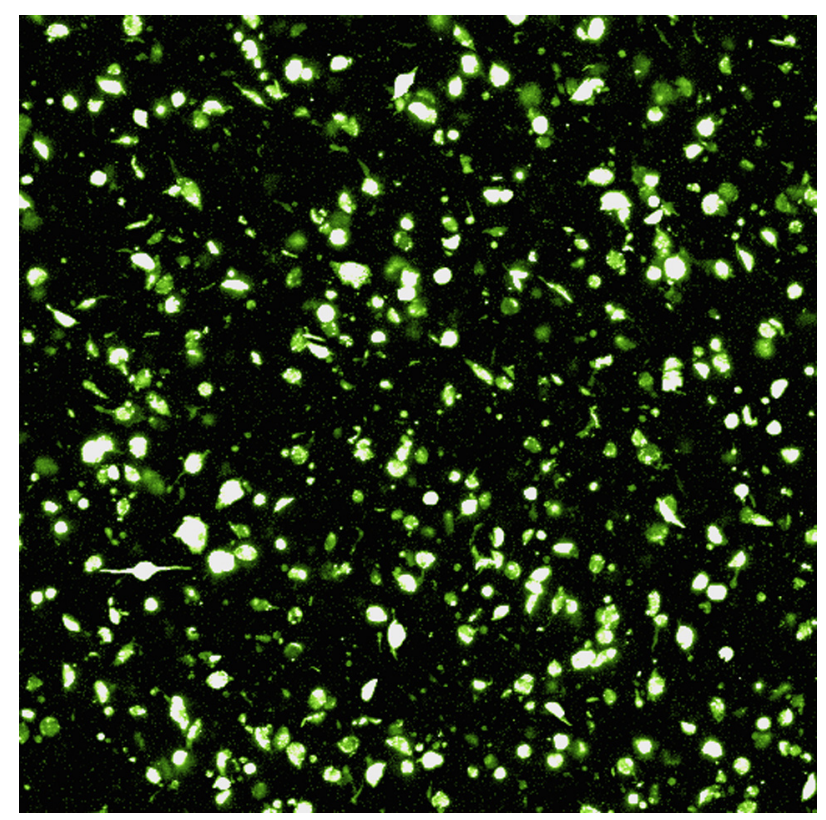

FIGURE 1. EPCs demonstrate characteristic spreading, in vitro, within the EPC fibrin hydrogel construct 2 days after construct $(10 \mathrm{mg} / \mathrm{mL}$ fibrin, $17 \times 10^{6} \mathrm{EPCs} / \mathrm{mL}$ ) creation (eGFP ${ }^{+} \mathrm{EPCs}$, confocal microscopy, $20 \times$ magnification).

ventricle. ${ }^{12-17}$ After LAD ligation, the animals were randomized to 1 of 8 groups: control (coronary ligation alone), implant of a fibrin patch without cells ( $10 \mathrm{mg} / \mathrm{mL}$ [FIB 10] or $20 \mathrm{mg} / \mathrm{mL}$ [FIB 20]), injection of EPCs (IC, 2 million cells/in $250 \mu \mathrm{L}$ PBS), or implant of EPC-fibrin hydrogel $(10 \mathrm{mg} /$ $\mathrm{mL}$ fibrin $7 \times 10^{6} \mathrm{EPCs} / \mathrm{mL}, 10 \mathrm{mg} / \mathrm{mL}$ fibrin $17 \times 10^{6} \mathrm{EPCs} / \mathrm{mL}, 20$ $\mathrm{mg} / \mathrm{mL}$ fibrin $7 \times 10^{6} \mathrm{EPCs} / \mathrm{mL}, 20 \mathrm{mg} / \mathrm{mL}$ fibrin $17 \times 10^{6} \mathrm{EPCs} / \mathrm{mL}$ ). The constructs were sutured in place with a 7-0 Prolene suture over the area of myocardial injury with the cellular surface facing the myocardium. The thoracotomy was closed in 3 layers, and the animals were allowed to recover. Four weeks after myocardial infarction, the animals were sacrificed after hemodynamic analysis for histologic analysis.

\section{Confirmation of Endothelial Progenitor Cell Migration Into the Myocardium}

Our first step, in vivo, was to establish that EPCs from the construct had the ability to migrate from the construct into the myocardium. To assess EPC migration, $\mathrm{eGFP}^{+}$EPCs from transgenic rats were used to create the construct $\left(20 \mathrm{mg} / \mathrm{mL}\right.$ fibrin, $\left.17 \times 10^{6} \mathrm{EPCs} / \mathrm{mL}\right)$. This construct was then implanted onto ischemic myocardium after LAD ligation. The hearts were explanted 1 week after implant, flushed with PBS, and distended with optical cutting temperature embedding compound (Electron Microscopy Sciences, Hatfield, Pa). Visualization was performed in the peri-infarct border zone, which was defined as 1 microscopic field from the infarct. Hearts treated with construct were compared with IC. Sections were briefly washed, fixed in $4 \%$ paraformaldehyde, and stained for anti-GFP and anti- $\alpha$ smooth muscle actin (SMA, pericytes). Primary antibodies used for indirect immunofluorescence were goat anti-GFP (1:200, Rockland, Gilbertsville, Pa) and rabbit anti-SMA (1:150, Abcam, Cambridge, England). Secondary antibodies included donkey anti-goat conjugated to fluorescein isothiocyanate (FITC) (1:200, Abcam) and donkey anti-rabbit conjugated to Alexa Fluor 594 (1:200, Abcam). Nuclei were counterstained with 4',6-diamidino-2phenylindole (DAPI) (Vector Laboratories, Burlingame, Calif). Construct was compared with control (isolated LAD ligation) and IC.

\section{Quantification of Myocardial Vasculogenesis}

Sections were briefly washed 3 times in PBS, fixed in 4\% paraformaldehyde for 10 minutes at room temperature, and blocked in $10 \%$ fetal bovine serum (Gibco) for 1 hour at $37^{\circ} \mathrm{C}$. Primary antibodies were diluted 1:150 in PBS and incubated for 2 hours at $37^{\circ} \mathrm{C}$. Secondary antibodies were diluted in PBS and incubated for 1 hour at $37^{\circ} \mathrm{C}$. Primary antibodies included sheep anti-von Willebrand factor (endothelial cells of
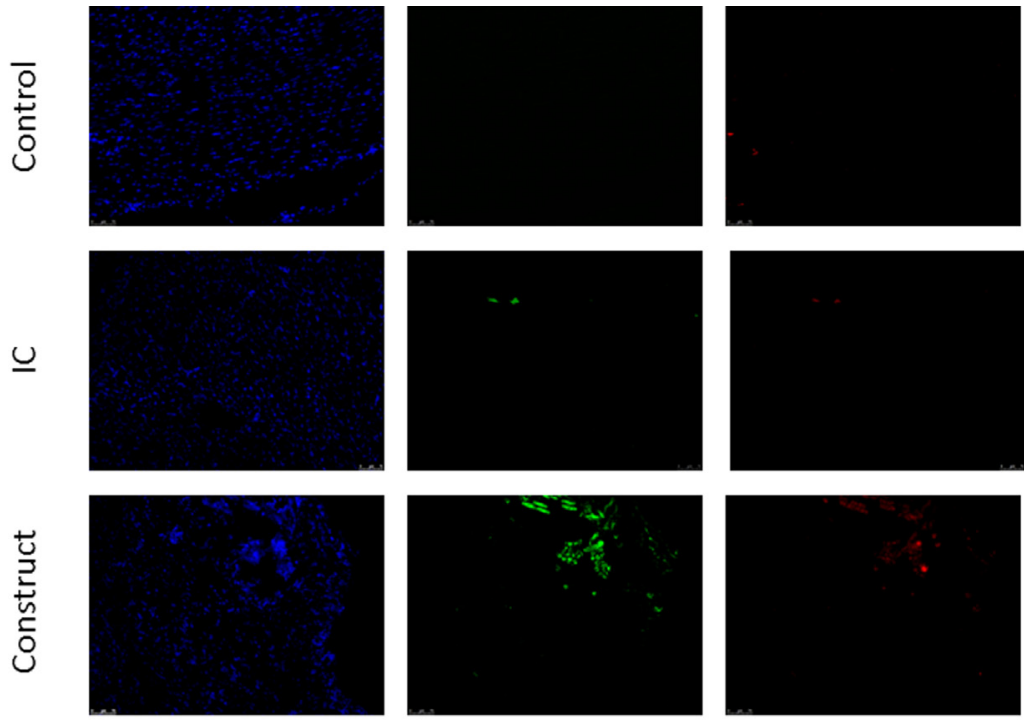

DAPI

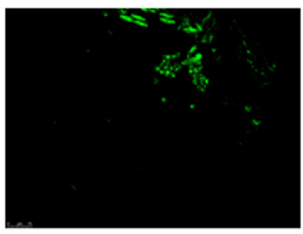

eGFP

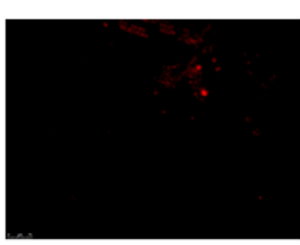

$\alpha-$ SMA
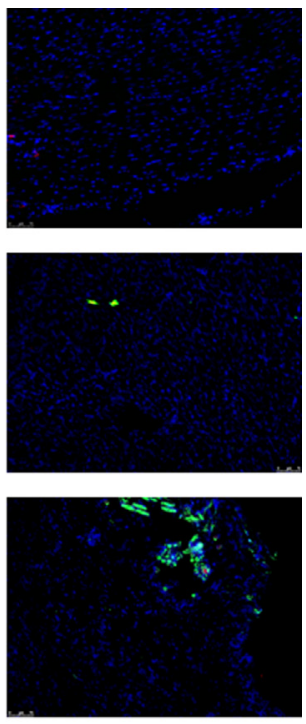

merged

FIGURE 2. Immunofluorescent imaging of $\mathrm{GGF}^{+}$transgenic EPCs migration from the EPC-fibrin construct to the myocardium. Sections were triple stained for nuclei (DAPI, blue), eGFP (green), and $\alpha$-SMA (red) $(20 \times$ magnification, scale bar $=75 \mu \mathrm{m})$. DAPI, 4',6-diamidino-2-phenylindole; $e G F P$, enhanced green fluorescent protein; SMA, smooth muscle actin; IC, injection of EPCs. 


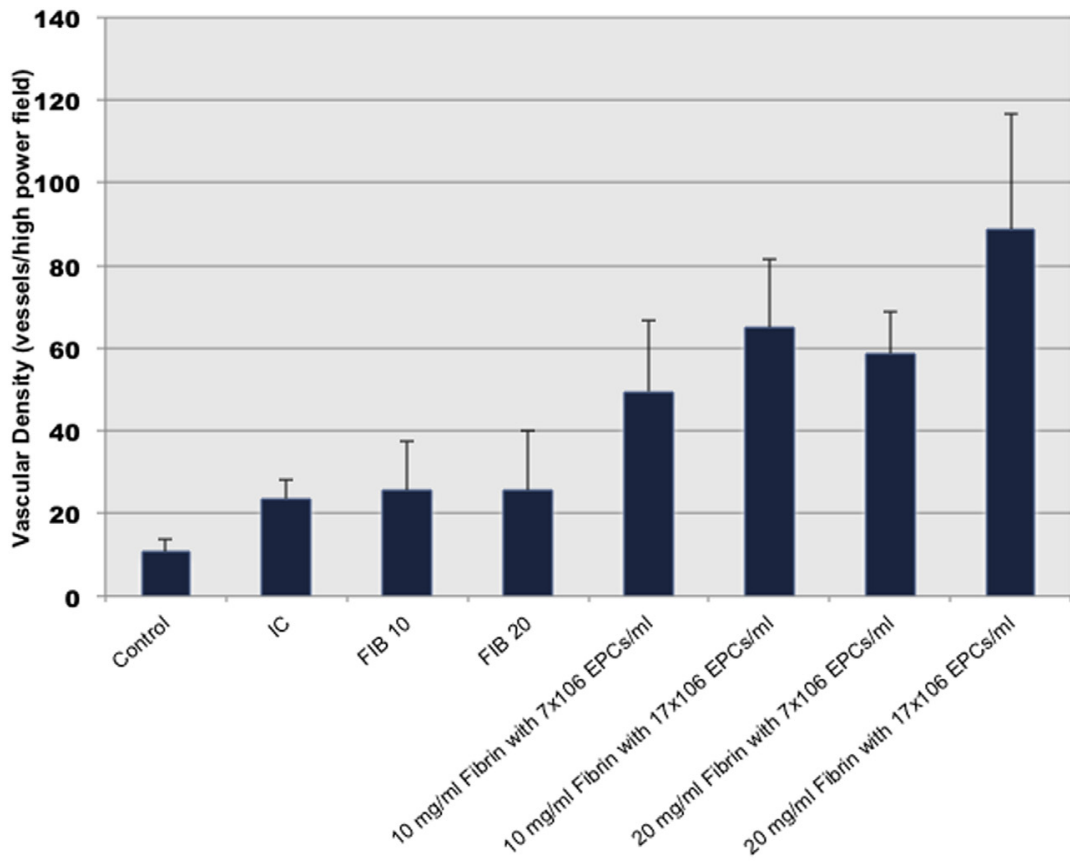

\begin{tabular}{|c|c|c|c|}
\hline & Vessels/hpf & p vs. control & p vs. IC \\
\hline Control $(n=9)$ & $10.8 \pm 2.9$ & & 0.0003 \\
\hline IC $(n=6)$ & $23.7 \pm 4.5$ & 0.0003 & \\
\hline FIB $10(n=14)$ & $25.7 \pm 11.9$ & 0.0004 & 0.6 \\
\hline FIB $20(n=17)$ & $25.6 \pm 14.2$ & 0.0006 & 0.7 \\
\hline $10 \mathrm{mg} / \mathrm{ml}$ Fibrin with $7 \times 10^{6} \mathrm{EPCs} / \mathrm{ml}(\mathrm{n}=14)$ & $49.6 \pm 17.4$ & 0.000001 & 0.001 \\
\hline $10 \mathrm{mg} / \mathrm{ml}$ Fibrin with $17 \times 10^{6} \mathrm{EPCs} / \mathrm{ml}(\mathrm{n}=9)$ & $64.9 \pm 16.5$ & 0.000007 & 0.00003 \\
\hline $20 \mathrm{mg} / \mathrm{ml}$ Fibrin with $7 \times 10^{6} \mathrm{EPCs} / \mathrm{ml}(\mathrm{n}=10)$ & $64.6 \pm 10.0$ & 0.000000008 & 0.0000001 \\
\hline $20 \mathrm{mg} / \mathrm{ml}$ Fibrin with $17 \times 10^{6} \mathrm{EPCs} / \mathrm{ml}(\mathrm{n}=10)$ & $88.8 \pm 27.7$ & 0.00003 & 0.00003 \\
\hline
\end{tabular}

FIGURE 3. Quantification of myocardial neovasculogenesis within the ischemic peri-infarct myocardium. EPC, Endothelial progenitor cell; $h p f$, high power field; IC, injection of EPCs; FIB, fibrin patch without cells.

vasculature) conjugated to FITC (Abcam) and rabbit anti-SMA (Abcam). Secondary antibodies (1:200) were donkey anti-goat conjugated to FITC (Abcam), and donkey anti-rabbit conjugated to Alexa Fluor 594 (Abcam). Nuclei were stained with DAPI (Vector Laboratories). Vasculature was quantified using ImageJ (National Institutes of Health, Bethesda, Md). Measurements were made 1 high power field (hpf) from the infarct at $20 \times$ magnification.

\section{Analysis of Myocardial Fibrosis}

Hearts were explanted from animals, flushed with PBS, and distended with Tissue Tek (Sakura Finetek USA Inc, Torrance, Calif) optimum cutting temperature compound. Hearts were then submerged in optimum cutting temperature and frozen at $-80^{\circ} \mathrm{C} ; 10-\mu \mathrm{m}$-thick sections were prepared from each heart using a cryostat at the level of the midpapillary muscles. Masson's trichrome stain was performed on the sections using the Accustain Trichrome Stains Kit (Sigma) according to the manufacturer's instructions. Stained slides were scanned and images were analyzed in ImageJ (National Institutes of Health) to assess scar fraction.

\section{Analysis of Global Ventricular Function}

Before explanting the heart, transthoracic echocardiography was performed to assess myocardial function (Phillips [Andover, Mass] Sonos 5500 revD system with an S12 probe at $12 \mathrm{MHz}$ and a 3-cm depth of penetration). Ventricular measurements were performed according to the American Society for Echocardiography leading-edge method. Subsequently, A 2F pressure-volume catheter (Millar Instruments, Houston, Tex) was inserted into the left ventricle retrograde via the right common carotid artery for analysis of left ventricular function. In addition to steady-state hemodynamic parameters, contractility was determined from pressure-volume relationships obtained by reducing preload via occlusion of the inferior vena cava. After echocardiographic and pressure-volume analysis, a midline sternotomy was performed and a 2.5 - $\mathrm{mm}$ ascending aortic flow probe (Transonic Systems Inc, Ithaca, NY) was placed for Doppler analysis of cardiac output.

\section{Statistical Analysis}

Quantitative data are expressed as means \pm standard error of the mean. Statistical significance was evaluated using the unpaired Student $t$ test for comparison between 2 means. 
Control
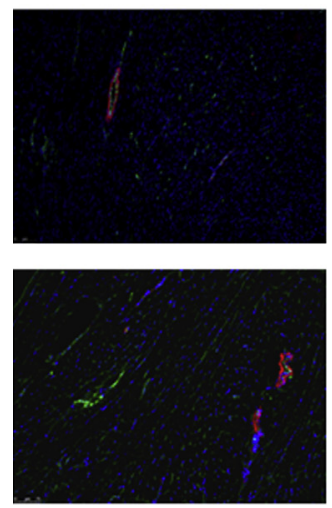

$10 \mathrm{mg} / \mathrm{ml} \mathrm{Fibrin}$ $7 \times 10^{6} \mathrm{EPCs}$
IC
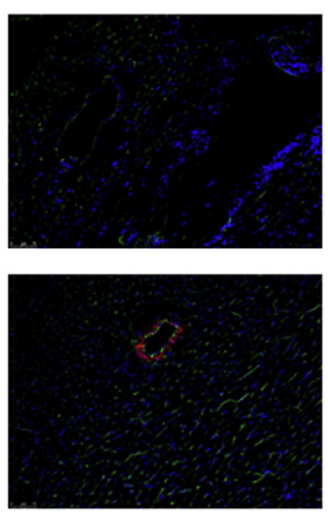

$10 \mathrm{mg} / \mathrm{ml} \mathrm{Fibrin}$

$17 \times 10^{5} \mathrm{EPCs}$
FIB 10
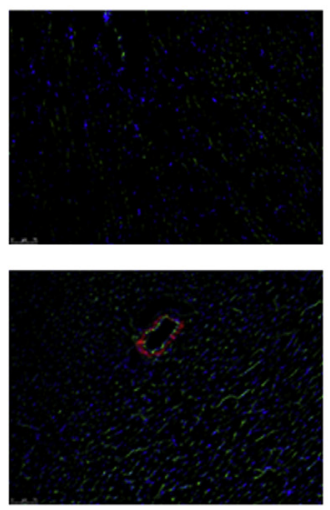

$20 \mathrm{mg} / \mathrm{ml} \mathrm{Fibrin}$

$7 \times 10^{6} \mathrm{EPCs}$
FIB 20
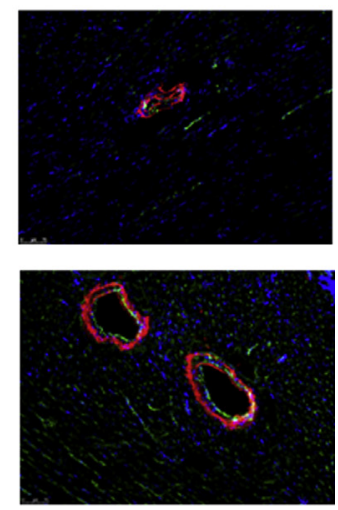

$20 \mathrm{mg} / \mathrm{ml} \mathrm{Fibrin}$ $17 \times 10^{6} \mathrm{EPCs}$

FIGURE 4. Representative immunofluorescent images demonstrating vascular density in peri-infarct ischemic myocardium after therapy (20 $\times$ magnification; green $=$ von Willebrand factor, blue $=\mathrm{DAPI}$, red $=\alpha \mathrm{SMA}) . E P C$, Endothelial progenitor cell; IC, injection of EPCs; $F I B$, fibrin patch without cells.

\section{RESULTS}

Endothelial Progenitor Cells Remain Viable Within the Engineered Fibrin Construct

To ensure viability of EPCs within the fibrin hydrogel construct, in vitro, live-dead stain was analyzed. Quantification of viability revealed significant viability of EPCs within the construct at 2 days (Table 1). Lower viability was noted with prolonged time. Excellent viability was noted to 10 days after implant in the construct, in vitro. Confocal imaging demonstrated characteristic EPC spreading and migration by 2 days within the construct (Figure 1).

\section{Robust Endothelial Progenitor Cell Migration From the Construct to Ischemic Myocardium}

Establishing migratory potential of $\mathrm{eGFP}^{+}$EPCs from the engineered EPC fibrin construct to the ischemic myocardium helps to determine the vasculogenic potential of this therapy. Immunofluorescent microscopy demonstrated a marked number of EPCs within the deep myocardium, indicating significant migration of EPCs from the construct. When compared with control, a statistically significant number of EPCs were noted within the deep myocardium $(28.5 \pm 12.3$ cells/hpf vs 0 cells/hpf, $\mathrm{n}=5$ / group, $P<.00001)$. In addition, when compared with IC there was a markedly increased number of delivered EPCs within the myocardium $(28 \pm 12.3$ cells/hpf vs $2.4 \pm 2.1$ cells/hpf, $\mathrm{n}=6$ /group, $P=.0001$ ), denoting enhanced delivery efficiency with the construct compared with IC (Figure 2).

\section{Tissue-Engineered Endothelial Progenitor Cell-Fibrin Hydrogel Construct Implant Enhances Myocardial Vasculogenesis}

Quantification of myocardial vasculogenesis demonstrated a statistically significant increase in neovasculogenesis within the ischemic myocardium after treatment with all 4 EPC fibrin constructs when compared with control (Figure 3). Furthermore, all 4 construct treatment groups had a statistically significant increase in neovasculogenesis when compared with IC. This demonstrates that enhanced cell retention may contribute to enhanced vasculogenesis. Of note, the isolated, empty fibrin gels (FIB 10 and FIB 20) also demonstrated increased vascular density when compared with control. The construct with the high cell and high density $\left(20 \mathrm{mg} / \mathrm{mL}\right.$ fibrin $\left.17 \times 10^{6} \mathrm{EPCs} / \mathrm{mL}\right)$

TABLE 2. Left ventricular myocardial scar fraction 4 weeks after left anterior descending coronary artery ligation and treatment

\begin{tabular}{lcc}
\hline & Left ventricular infarct & $P$ vs control \\
\hline Control $(\mathrm{n}=7)$ & $13.0 \% \pm 5.5 \%$ & \\
IC $(\mathrm{n}=6)$ & $8.2 \% \pm 3.0 \%$ & .0009 \\
FIB $10(\mathrm{n}=13)$ & $11.7 \% \pm 5.6 \%$ & .0009 \\
FIB $20(\mathrm{n}=16)$ & $12.3 \% \pm 11.8 \%$ & .5 \\
$10 \mathrm{mg} / \mathrm{mL}$ fibrin with $7 \times 10^{6} \mathrm{EPCs} / \mathrm{mL}(\mathrm{n}=11)$ & $6.2 \% \pm 3.7 \%$ & .02 \\
$10 \mathrm{mg} / \mathrm{mL}$ fibrin with $17 \times 10^{6} \mathrm{EPCs} / \mathrm{mL}(\mathrm{n}=8)$ & $5.0 \% \pm 2.9 \%$ & .009 \\
$20 \mathrm{mg} / \mathrm{mL}$ fibrin with $7 \times 10^{6} \mathrm{EPCs} / \mathrm{mL}(\mathrm{n}=14)$ & $5.0 \% \pm 3.6 \%$ & .008 \\
$20 \mathrm{mg} / \mathrm{mL}$ fibrin with $17 \times 10^{6} \mathrm{EPCs} / \mathrm{mL}(\mathrm{n}=10)$ & .0002 & .004 \\
\hline
\end{tabular}

$E P C$, Endothelial progenitor cell; $I C$, injection of EPCs; $F I B$, fibrin patch without cells. 

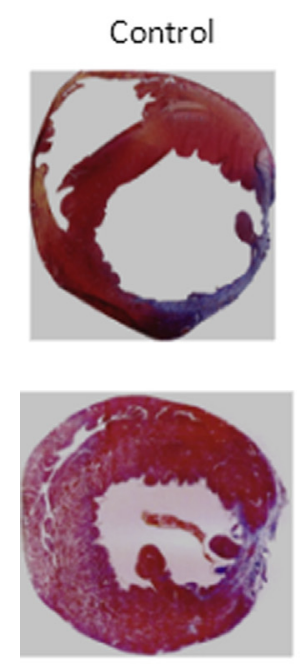

$10 \mathrm{mg} / \mathrm{ml} \mathrm{Fibrin}$ $7 \times 10^{6} \mathrm{EPCs}$
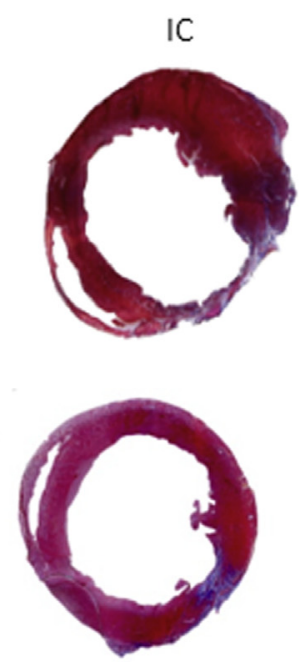

$10 \mathrm{mg} / \mathrm{ml}$ Fibrin $17 \times 10^{6} \mathrm{EPCs}$
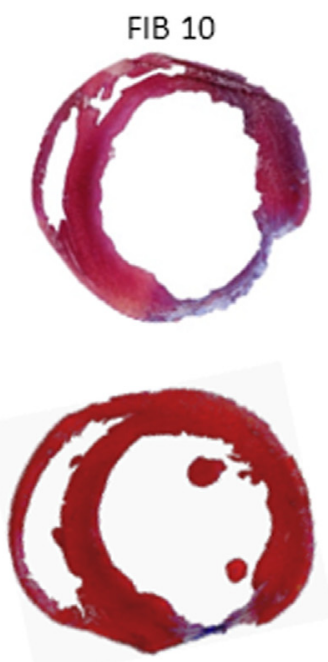

$20 \mathrm{mg} / \mathrm{ml}$ Fibrin $7 \times 10^{6} \mathrm{EPCs}$
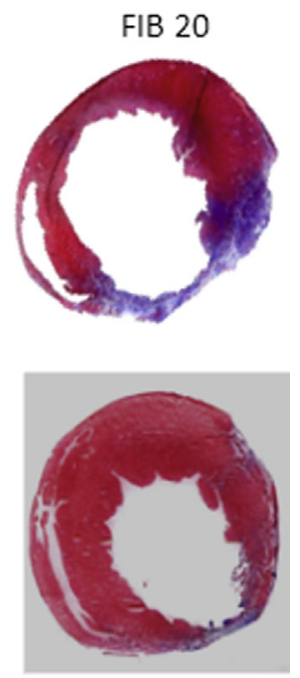

$20 \mathrm{mg} / \mathrm{ml}$ Fibrin $17 \times 10^{6} \mathrm{EPCs}$

FIGURE 5. Representative myocardial cross-sectional images after Masson's trichrome staining to delineate myocardial scar (scar $=b l u e$, myocardium $=r e d) . E P C$, Endothelial progenitor cell; $I C$, injection of EPCs; $F I B$, fibrin patch without cells.

demonstrated a statistically significant increase in vasculogenesis when compared with the $20 \mathrm{mg} / \mathrm{mL}$ fibrin $7 \times 10^{6}$ $\mathrm{EPC} / \mathrm{mL}(P=.02), 10 \mathrm{mg} / \mathrm{mL}$ fibrin $7 \times 10^{6} \mathrm{EPC} / \mathrm{mL}$ $(P=.001)$, and $10 \mathrm{mg} / \mathrm{mL}$ fibrin $17 \times 10^{6} \mathrm{EPC} / \mathrm{mL}$ $(P=.04)$. Both $20 \mathrm{mg} / \mathrm{mL}$ fibrin $7 \times 10^{6} \mathrm{EPC} / \mathrm{mL}$ and 10 $\mathrm{mg} / \mathrm{mL}$ fibrin $7 \times 10^{6} \mathrm{EPC} / \mathrm{mL}$ hydrogels demonstrated a significantly increased vasculogenic potential when compared with the low-density, low-cell construct (10 $\mathrm{mg} / \mathrm{mL}$ fibrin $\left.7 \times 10^{6} \mathrm{EPC} / \mathrm{mL}\right)(P=.02$ and .05 , respectively). There was no statistically significant difference in vasculogenesis between $20 \mathrm{mg} / \mathrm{mL}$ fibrin $7 \times 10^{6} \mathrm{EPC} /$ $\mathrm{mL}$ and $10 \mathrm{mg} / \mathrm{mL}$ fibrin $7 \times 10^{6} \mathrm{EPC} / \mathrm{mL}$ constructs $(P=.9)$ (Figure 4).

\section{Endothelial Progenitor Cell Fibrin Construct Implants Minimize Myocardial Fibrosis}

A marked reduction in myocardial fibrosis and ventricular scar was demonstrated with treatment with all 4 construct groups when compared with control (Table 2). Moreover, IC demonstrated a significant reduction in scar fraction when compared with control $(P=.0009)$. There was no significant difference in scar formation between isolated fibrin gel implant (FIB 10 or FIB 20) and control. All 4 construct groups demonstrated a statistically significant reduction in scar formation when compared with IC. There was no significant difference in scar fraction between the 4 EPC-fibrin hydrogel construct groups (Figure 5).

\section{Endothelial Progenitor Cell Fibrin Construct Implant Markedly Improves Myocardial Function}

Hemodynamic analysis demonstrated a statistically significant improvement in cardiac output, ejection fraction, contractility, $\mathrm{dP} / \mathrm{dT}$ max, and maximum generated pressure for all EPC-fibrin constructs when compared with IC and control (Table 3). There was no significant difference in hemodynamic function as measured by these parameters between the treatment groups. Maximum generated pressure was significantly higher for both FIB 10 and FIB 20 groups when compared with IC.

\section{DISCUSSION}

In this study, we demonstrate a robust vasculogenic response to therapy with construct-encapsulating EPCs. We witnessed a high rate of cell migration from the construct to the underlying ischemic myocardium. Moreover, there was a marked increase in vasculogenesis with prolonged exposure of EPCs to ischemic myocardium at a high concentration. This enhanced vasculogenesis appears to have contributed to reduced myocardial scar and likely subsequent preservation of myocardial structure and function. Over the past decade, numerous clinical trials have attempted to use cell injection techniques, whether it be direct myocardial injection, endocardial catheter-based injection, or intracoronary delivery. None of these techniques have demonstrated a clinically significant benefit that would successfully affect long-term survival. ${ }^{18-26}$ Novel tissueengineered therapies as outlined in this article may provide the ability to overcome the limitations of cell dispersal and engraftment that have thus far limited clinical trials exploring cell therapy.

Hydrogels have the unique ability to slowly degrade, in a controlled fashion, and therefore provide a continuous and long-term exposure of cytokines or cell therapy to the myocardium. ${ }^{27,28}$ It is important to ensure that the desired 
TABLE 3. Left ventricular function assessed 4 weeks after left anterior descending ligation and treatment

\begin{tabular}{|c|c|c|c|c|c|c|c|c|}
\hline & $\begin{array}{l}\text { Control } \\
(\mathbf{n}=10)\end{array}$ & IC $(n=6)$ & FIB $10(n=9)$ & FIB $20(n=11)$ & $\begin{array}{c}10 \mathrm{mg} / \mathrm{mL} \text { fibrin } \\
\text { with } 7 \times 10^{6} \\
\text { EPCs } / \mathrm{mL}(\mathrm{n}=9)\end{array}$ & $\begin{array}{c}10 \mathrm{mg} / \mathrm{mL} \text { fibrin } \\
\text { with } 17 \times 10^{6} \\
\text { EPCs } / \mathrm{mL}(\mathrm{n}=7)\end{array}$ & $\begin{array}{l}\quad 20 \mathrm{mg} / \mathrm{mL} \\
\text { fibrin with } 7 \times 10^{6} \\
\text { EPCs } / \mathrm{mL}(\mathrm{n}=10)\end{array}$ & $\begin{array}{c}20 \mathrm{mg} / \mathrm{mL} \text { fibrin } \\
\text { with } 17 \times 10^{6} \\
\text { EPCs } / \mathrm{mL}(\mathrm{n}=12)\end{array}$ \\
\hline $\mathrm{CO}(\mathrm{mL} / \mathrm{min})$ & $24.5 \pm 5.4$ & $22.6 \pm 4.7$ & $25.4 \pm 10.8(P=.6)$ & $21.0 \pm 13.1(P=.8)$ & $30.5 \pm 2.0(P=.006)$ & $33.7 \pm 3.5(P=.001)$ & $33.7 \pm 6.8(P=.01)$ & $32.5 \pm 4.9(P=.006)$ \\
\hline $\mathrm{EF}(\%)$ & $39.7 \pm 14.2$ & $39.8 \pm 12.2$ & $44.8 \pm 15.6(P=.6)$ & $41.4 \pm 21.8(P=.9)$ & $66.3 \pm 8.2(P=.0006)$ & $68.8 \pm 10.7(P=.007)$ & $69.7 \pm 6.4(P=.00002)$ & $61.7 \pm 13.8(P=.0009)$ \\
\hline $\begin{array}{l}\text { Maximum } \\
\text { pressure } \\
(\mathrm{mm} \mathrm{Hg})\end{array}$ & $62.7 \pm 14.5$ & $63.6 \pm 9.4$ & $88.2 \pm 8.7(P=.001)$ & $84.2 \pm 16.8(P=.02)$ & $106.2 \pm 15.4(P=.0006)$ & $109.1 \pm 23.3(P=.007)$ & $101.8 \pm 13.7(P=.0001)$ & $107.9 \pm 20.4(P=.002)$ \\
\hline $\begin{array}{l}\text { Contractility } \\
\qquad(\mu \mathrm{L} / \mathrm{mm} \mathrm{Hg})\end{array}$ & $0.57 \pm 0.14$ & $0.88 \pm 0.21$ & $1.01 \pm 0.24(P=.5)$ & $1.08 \pm 0.48(P=.5)$ & $2.23 \pm 1.05(P=.03)$ & $1.77 \pm 0.24(P=.008)$ & $2.32 \pm 0.67(P=.005)$ & $2.50 \pm 0.82(P=.005)$ \\
\hline $\begin{array}{l}\mathrm{dP} / \mathrm{dt} \max \\
\quad(\mathrm{mm} \mathrm{Hg} / \mathrm{sec})\end{array}$ & $2156 \pm 677$ & $2691 \pm 554$ & $3880 \pm 758(P=.01)$ & $3728 \pm 1185(P=.06)$ & $5011 \pm 1281(P=.008)$ & $5090 \pm 1257(P=.002)$ & $6686 \pm 2587(P=.03)$ & $5970 \pm 1661(P=.004)$ \\
\hline
\end{tabular}

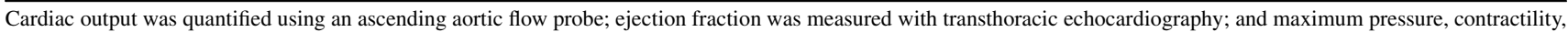
and dPdt were measured with an intraventricular pressure-volume catheter. $P$ values are in relation to IC. $C O$, Cardiac output; $E F$, ejection fraction; $E P C$, endothelial progenitor cell; $I C$, injection of EPCs; FIB, fibrin patch without cells.

hydrogel has biologic compatibility and will allow for appropriate cell migration and differentiation. ${ }^{29}$ Cell density, adhesive ligands, and gel stiffness intrinsic to the gels can dramatically alter stem cell fate; thus, it is vital to carefully control these factors to maximize stem cell potential. ${ }^{30}$ On the basis of our in vitro analysis, we found 10 $\mathrm{mg} / \mathrm{mL}$ and $20 \mathrm{mg} / \mathrm{mL}$ gels to have desirable stiffness to allow cell sprouting and spreading. In addition, this density seemed to allow maximum cell migration. As was evident in this study, no significant differences in vasculogenesis or hemodynamics were present between 7 and 17 million EPCs/mL cell densities.

Fibrin is desirable for cell-delivery applications given its inherent biocompatibility and ability to maintain encapsulated cell viability. ${ }^{31,32}$ In addition, tissue-engineered EPC fibrin constructs as used in this study easily can be translated to the clinical arena, given preexistent Food and Drug Administration approval. In fact, fibrin sealant and glues are widely used in cardiac surgery and other surgical specialties for hemostatic applications. Moreover, fibrin has been studied for its intrinsic angiogenic abilities. ${ }^{33}$ Previous studies have demonstrated a statistically significant increase in myocardial angiogenesis and endothelialization. ${ }^{34-36}$ Likewise, we have demonstrated the intrinsic angiogenic capabilities of fibrin in our studies when compared with control. This intrinsic angiogenic potential may explain the enhanced vasculogenesis and diminished fibrosis that we witnessed with both FIB 10 and FIB 20 groups in this study. This angiogenic capability likely further complements the vasculogenesis and improved function we have noticed in this study with EPC fibrin constructs, thereby maximizing vasculogenic response beyond that of the delivered EPCs with the constructs.

Tissue engineering, as used in this study, may provide the ability to overcome the limitations that we have witnessed over the past decade with cell-based therapies. These novel approaches may allow investigators to enhance the delivery of desired cells, use multiple cell types, incorporate concomitant cytokine therapy, and provide gel-mediated myocardial stabilization. Intricate tissue-engineered celldelivery strategies, as exemplified in this study, may provide the robust clinical response needed to normalize myocardial function.

\section{CONCLUSIONS}

We present a novel tissue-engineered, hydrogel-based, EPC-mediated therapy to enhance cell delivery, cell retention, vasculogenesis, and preservation of myocardial structure and function. This therapeutic strategy may provide the ability to overcome the limitations of cell dispersal and engraftment associated with prior cell-based clinical therapies.

\section{References}

1. Araszkiewicz A, Grajek S, Lesiak M, Prech M, Pyda M, Janus M, et al. Effect of impaired myocardial reperfusion on left ventricular remodeling in patients with anterior wall acute myocardial infarction treated with primary coronary intervention. Am J Cardiol. 2006;98:725-8.

2. Bolognese L, Carrabba N, Parodi G, Santoro GM, Buonamici P, Cerisano G, et al. Impact of microvascular dysfunction on left ventricular remodeling and longterm clinical outcome after primary coronary angioplasty for acute myocardial infarction. Circulation. 2004;109:1121-6.

3. Velazquez EJ, Lee KL, Deja MA, Jain A, Sopko G, Marchenko A, et al. Coronary-artery bypass surgery in patients with left ventricular dysfunction. $N$ Engl J Med. 2011;364:1607-16.

4. Sheikh AY, Huber BC, Narsinh KH, Spin JM, van der Bogt K, de Almeida PE, et al. In vivo functional and transcriptional profiling of bone marrow stem cells after transplantation into ischemic myocardium. Arterioscler Thromb Vasc Biol. 2012;32:92-102.

5. Hofmann M, Wollert KC, Meyer GP, Menke A, Arseniev L, Hertenstein B, et al. Monitoring of bone marrow cell homing into the infarcted human myocardium. Circulation. 2005;111:2198-202.

6. Schachinger V, Aicher A, Dobert N, Rover R, Diener J, Fichtlscherer S, et al. Pilot trial on determinants of progenitor cell recruitment to the infarcted human myocardium. Circulation. 2008;118:1425-32.

7. Li SH, Lai TY, Sun Z, Han M, Moriyama E, Wilson B, et al. Tracking cardiac engraftment and distribution of implanted bone marrow cells: comparing intraaortic, intravenous, and intramyocardial delivery. J Thorac Cardiovasc Surg. 2009; 137:1225-33.e1

8. Zhang Y, Ingram DA, Murphy MP, Saadatzadeh MR, Mead LE, Prater DN, et al. Release of proinflammatory mediators and expression of proinflammatory adhesion molecules by endothelial progenitor cells. Am J Physiol Heart Circ Physiol. 2009;296:H1675-82.

9. Tse HF, Siu CW, Zhu SG, Songyan L, Zhang QY, Lai WH, et al. Paracrine effects of direct intramyocardial implantation of bone marrow derived cells to enhance neovascularization in chronic ischaemic myocardium. Eur J Heart Fail. 2007;9: $747-53$.

10. Hakamata Y, Tahara K, Uchida H, Sakuma Y, Nakamura M, Kume A, et al. Green fluorescent protein-transgenic rat: a tool for organ transplantation research. Biochem Biophys Res Commun. 2001;286:779-85.

11. Frederick JR, Fitzpatrick JR III, McCormick RC, Harris DA, Kim AY, Muenzer JR, et al. Stromal cell-derived factor-1alpha activation of 
tissue-engineered endothelial progenitor cell matrix enhances ventricular function after myocardial infarction by inducing neovasculogenesis. Circulation. 2010;122:S107-17.

12. Atluri P, Trubelja A, Fairman AS, Hsiao P, MacArthur JW, Cohen JE, et al. Normalization of postinfarct biomechanics using a novel tissue-engineered angiogenic construct. Circulation. 2013;128:S95-104.

13. Jayasankar V, Pirolli TJ, Bish LT, Berry MF, Burdick J, Grand T, et al. Targeted overexpression of growth hormone by adenoviral gene transfer preserves myocardial function and ventricular geometry in ischemic cardiomyopathy. $J$ Mol Cell Cardiol. 2004;36:531-8.

14. Liu YH, Yang XP, Nass O, Sabbah HN, Peterson E, Carretero OA. Chronic heart failure induced by coronary artery ligation in Lewis inbred rats. Am J Physiol. 1997;272:H722-7.

15. Woo YJ, Panlilio CM, Cheng RK, Liao GP, Atluri P, Hsu VM, et al. Therapeutic delivery of cyclin A2 induces myocardial regeneration and enhances cardiac function in ischemic heart failure. Circulation. 2006;114:I206-13.

16. Jayasankar V, Bish LT, Pirolli TJ, Berry MF, Burdick J, Woo YJ. Local myocardial overexpression of growth hormone attenuates postinfarction remodeling and preserves cardiac function. Ann Thorac Surg. 2004;77:2122-9.

17. MacArthur JW Jr, Trubelja A, Shudo Y, Hsiao P, Fairman AS, Yang E, et al. Mathematically engineered stromal cell-derived factor-1alpha stem cell cytokine analog enhances mechanical properties of infarcted myocardium. J Thorac Cardiovasc Surg. 2013;145:278-84.

18. Ruel M, Laham RJ, Parker JA, Post MJ, Ware JA, Simons M, et al. Long-term effects of surgical angiogenic therapy with fibroblast growth factor 2 protein. $J$ Thorac Cardiovasc Surg. 2002;124:28-34.

19. Simons M, Annex BH, Laham RJ, Kleiman N, Henry T, Dauerman H, et al. Pharmacological treatment of coronary artery disease with recombinant fibroblast growth factor-2: double-blind, randomized, controlled clinical trial. Circulation. 2002; 105:788-93.

20. Grines CL, Watkins MW, Mahmarian JJ, Iskandrian AE, Rade JJ, Marrott P, et al. A randomized, double-blind, placebo-controlled trial of Ad5FGF-4 gene therapy and its effect on myocardial perfusion in patients with stable angina. J Am Coll Cardiol. 2003:42:1339-47.

21. Assmus B, Honold J, Schachinger V, Britten MB, Fischer-Rasokat U, Lehmann R, et al. Transcoronary transplantation of progenitor cells after myocardial infarction. N Engl J Med. 2006;355:1222-32.

22. Schachinger V, Erbs S, Elsasser A, Haberbosch W, Hambrecht R, Holschermann $\mathrm{H}$, et al. Intracoronary bone marrow-derived progenitor cells in acute myocardial infarction. $N$ Engl J Med. 2006;355:1210-21.

23. Wollert KC, Meyer GP, Lotz J, Ringes-Lichtenberg S, Lippolt P, Breidenbach C, et al. Intracoronary autologous bone-marrow cell transfer after myocardial infarction: the BOOST randomised controlled clinical trial. Lancet. 2004;364: $141-8$.

24. Yang J, Ii M, Kamei N, Alev C, Kwon SM, Kawamoto A, et al. CD34+ cells represent highly functional endothelial progenitor cells in murine bone marrow. PLoS One. 2011;6:e20219.

25. Mansour S, Roy DC, Bouchard V, Stevens LM, Gobeil F, Rivard A, et al. Oneyear safety analysis of the COMPARE-AMI trial: comparison of intracoronary injection of CD133 bone marrow stem cells to placebo in patients after acute myocardial infarction and left ventricular dysfunction. Bone Marrow Res. 2011;2011:385124.

26. Schuh A, Kroh A, Konschalla S, Liehn EA, Sobota RM, Biessen EA, et al. Myocardial regeneration by transplantation of modified endothelial progenitor cells expressing SDF-1 in a rat model. J Cell Mol Med. 2012;16:2311-20.

27. Macarthur JW Jr, Purcell BP, Shudo Y, Cohen JE, Fairman A, Trubelja A, et al. Sustained release of engineered stromal cell-derived factor 1-alpha from injectable hydrogels effectively recruits endothelial progenitor cells and preserves ventricular function after myocardial infarction. Circulation. 2013;128:S79-86.

28. Jiang B, Akar B, Waller TM, Larson JC, Appel AA, Brey EM. Design of a composite biomaterial system for tissue engineering applications. Acta Biomater. 2014;10:1177-86.

29. Kim P, Yuan A, Nam KH, Jiao A, Kim DH. Fabrication of poly(ethylene glycol): gelatin methacrylate composite nanostructures with tunable stiffness and degradation for vascular tissue engineering. Biofabrication. 2014;6:024112.

30. Lee J, Abdeen AA, Zhang D, Kilian KA. Directing stem cell fate on hydrogel substrates by controlling cell geometry, matrix mechanics and adhesion ligand composition. Biomaterials. 2013;34:8140-8.

31. Brandl A, Yuan Q, Boos AM, Beier JP, Arkudas A, Kneser U, et al. A novel early precursor cell population from rat bone marrow promotes angiogenesis in vitro. BMC Cell Biol. 2014;15:12.
32. Sun CK, Zhen YY, Leu S, Tsai TH, Chang LT, Sheu JJ, et al. Direct implantation versus platelet-rich fibrin-embedded adipose-derived mesenchymal stem cells in treating rat acute myocardial infarction. Int J Cardiol. 2014;173:410-23.

33. Kulkarni M, O'Loughlin A, Vazquez R, Mashayekhi K, Rooney P, Greiser U, et al Use of a fibrin-based system for enhancing angiogenesis and modulating inflammation in the treatment of hyperglycemic wounds. Biomaterials. 2014;35:2001-10.

34. Sacchi V, Mittermayr R, Hartinger J, Martino MM, Lorentz KM, Wolbank S, et al. Long-lasting fibrin matrices ensure stable and functional angiogenesis by highly tunable, sustained delivery of recombinant VEGF164. Proc Natl Acad Sci U S A. 2014;111:6952-7.

35. Walpoth BH, Zammaretti P, Cikirikcioglu M, Khabiri E, Djebaili MK, Pache JC et al. Enhanced intimal thickening of expanded polytetrafluoroethylene grafts coated with fibrin or fibrin-releasing vascular endothelial growth factor in the pig carotid artery interposition model. J Thorac Cardiovasc Surg. 2007;133:1163-70.

36. Zamora DO, Natesan S, Becerra S, Wrice N, Chung E, Suggs LJ, et al. Enhanced wound vascularization using a dsASCs seeded FPEG scaffold. Angiogenesis 2013;16:745-57

\section{Discussion}

Dr Elaine Tseng (San Francisco, Calif). You've elegantly presented that EPCs embedded within a fibrin matrix hydrogel after acute myocardial infarction increased vasculogenesis and improved cardiac contractility. Stem cells have held significant promise for the regeneration of cardiac myocardium but have been fraught with difficulty in cell survival and retention for its paracrine effects and arrhythmias from direct myocardial injection. This study is notable for demonstrating the ability of endothelial progenitor stem cells to migrate from the hydrogel into the injured myocardium after external patch placement of the biocompatible matrix.

Previously, not only various types of stem cells but also growth factors and matrix materials have been investigated. Can you comment on what might be the ideal combination for use in clinical trials, as your group has investigated these other growth factors and matrix components.

How do you envision bench-to-bedside translation and for what population of patients? For example, in this study myocardial infarction was acute, and this would require some requisite time for cell and matrix generation before operation versus chronic heart failure for patients with prior myocardial infarction.

Dr Atluri. I don't know that we have all the questions answered in terms of what the optimal components would be. We've started off looking at EPCs, but I do envision a construct that could incorporate multiple subcomponents (ie, cytokines, EPCs). I don't know that we even have the right phenotype for the EPC yet. But this is a start, at least, to begin looking at the ability to retain cells.

In terms of the timing, I think it would be dependent on the components. So from a vasculogenic strategy, it clearly makes sense to think of an acute intervention shortly after a myocardial infarction. Of course, immediately after a myocardial infarction the cell environment is fairly hostile given inflammation in the heart, so that may provide us the time to isolate cells.

From a chronic standpoint, a vasculogenic strategy does not make a lot of sense unless you want to preserve purely the border zone, so I think a myogenic strategy may make sense on a more chronic model. Of course, then we're dealing with the problems that have really plagued us over the last 10 years, which is incorporation of muscle or islands of muscle that may be 
arrhythmogenic and may not electrically communicate with the rest of the myocardium itself.

Dr Todd Rosengart (Houston, Tex). Congratulations, it's good to see that your group is continuing to focus attention on the question of how to improve delivery and retention of delivering exogenous cells to the myocardium.

You nicely include a live/dead cell assay, but I was surprised that you were satisfied with a $50 \%$ nonliving cell rate. Having that data, were you able to isolate those cells and discard them, or were they included in the injectate?

I was surprised that your cell delivery alone without fibrin did not result in much of an improvement over controls. I think your group has previously shown that cells alone, although not ideal, are still effective. So can you explain?

Dr Atluri. I was a little bit surprised by that data as well. I think it goes along with some of the clinical findings that were seen in terms of clinical therapies with isolated EPC therapy. We noticed small benefits in hemodynamic function. A majority of the benefits have been seen from a functional standpoint.

Our group has really seen benefits with cytokine therapy. In terms of isolated stem cell therapy, we've done mesenchymal stem cells but not isolated EPCs, so we haven't seen the benefit with the isolated EPCs.

This is somewhat of a preliminary study. We've seen lots of benefits in rodents that have not translated to the clinical arena, so the next step is to go to a large animal.

I've spent a lot of time debating this with my collaborators, the bioengineers. I don't know what to make of the 50\% viability at 10 days. I think the real analysis is in an in vivo setting rather than in vitro. I was happy with viability up-front, to know that the fibrin microenvironment was not hostile immediately to the cells themselves. I think the next step would be to look at viability within the gel in the in vivo implanted model.

Dr Rosengart. So you did not isolate out?

Dr Atluri. I did not isolate out, no.

Dr Bo Yang (Ann Arbor, Mich). Your stem cells treating infarction has been done clinically by the group at the University of Florida. They showed good magnetic resonance imaging of the repopulation of muscle cells, but they didn't see any improvement of the ejection fraction. I think that makes sense. Because if you popularize that scar area, or infarcted area, with muscle cells from stem cells you still have the ischemia. Your LAD is still ligated. You have no blood supply to the LAD territory; that's why there is no increase of ejection fraction. Your data showed significant improvement of the heart function. Do you have an explanation?

From the catheter system, there are load-independent parameters for the contractility, such as PRA, end-systolic pressurevolume relationship, and dP/dt versus VED. Why didn't you use those parameters instead of ejection fraction, which is a load-dependent parameter?

Dr Atluri. Yes, we looked at our contractility at the slope of the end-systolic pressure-volume relationship and tried to eliminate our load dependence in that situation. I'd put more credibility in our slope of contractility than I would our ejection fraction, which is largely a qualitative assay anyways.

Dr Yang. I didn't see your data or any difference between those 2 groups.

Dr Atluri. There was improved contractility among our 4 treatment groups. There was no difference in contractility with a denser gel or with more cells that were implanted.

Dr Yang. The LAD still ligated. Do you have an explanation for this change of ejection fraction?

Dr Atluri. I think it's because of the enhanced vasculature from a microenvironment. You're right, this is still inferential and it's actually a perfusion analysis, so that will be the next step.

Dr John Mayer (Boston, Mass). You didn't tell us about how thick the patch is. Could you tell us that?

Dr Atluri. I actually haven't measured the patch. It's usually $100 \mu \mathrm{L}$ that we put onto the Vicryl mesh, so it's a fairly thin patch. That's why I think it's still a preliminary study because it allows us to do this on a rodent, and you can still get diffusion nutrients. But that's the reason why I don't think it's going to be scalable in its current form to a clinical setting.

Dr Mayer. I would ask you to think about the idea that maybe what you're doing is altering the postinfarct inflammatory process by virtue of this intervention as opposed to necessarily doing something about the vascular bed immediately. In Juan MeleroMartin's studies from our institution where he is creating vascularized implants, it takes days for his Matrigel implants containing EPCs and mesenchymal stem cells to form a vasculature that connects to the host vasculature. I wonder if there isn't an alternate explanation besides just growing more blood vessels.

Dr Atluri. Thank you. 